\title{
PENDEKATAN EVALUASI PROGRAM TYLER: GOAL-ORIENTED
}

\author{
Rina Novalinda ${ }^{1}$, Ambiyar $^{2}$, Fahmi Rizal $^{3}$ \\ ${ }^{1}$ Refraksi Optik, YLPTK, Padang, Jalan Berok Raya Nomor 1, Kurao Pagang, \\ Kecamatan Nanggalo, Kota Padang, Sumatera Barat - 25173 \\ ${ }^{2,3}$ Fakultas Teknik, Universitas Negeri Padang, Jalan Prof. Dr. Hamka, Air Tawar, \\ Kecamatan Padang Utara, Sumatera Barat - 25173 \\ 1e-mail: rinanovalinda78@gmail.com
}

\begin{abstract}
Abstrak
Beragam model yang diterapkan guna menyurvei program maupun kegiatan di berbagai bidang, seperti bidang hukum, pollitik, budaya, pendidikan, serta ekonomi. Evaluasi program pendidikan ialah prosedur penggambaran, menghimpun data/fakta serta penyajian informasi untuk pengambil kesimpulan selanjutnya akan digunakan untuk mempertimbangakan program tersebut, perlukah dibenahi, disudahi ataupun diteruskan. Menurut pandangan Ralph W Tyler, evaluasi sebagai suatu proses untuk memastikan sampai terealisasi atau tidaknya suatu goals. Penetapan terealisasi atau tidaknya goals, dirumuskan dalam tujuh tahap/langkah evaluasi berorientasi tujuan oleh Tyler. Tujuan penulisan artikel adalah untuk menggambarkan konsep/ide, tahap serta goals dari evaluasi menurut Ralph W Tyler. Evaluasi merupakan kegiatan penelaahan petunjuk secara terstruktur untuk memberikan sebuah keputusan atau nilai, telah atau belum tercapainya tujuan yang diharapkan.
\end{abstract}

Kata Kunci: evaluasi program, orientasi tujuan, pendekatan Tyler.

\begin{abstract}
There are many models applied to enlarge programs/activities in various fields, both in the fields of law, politics, culture, economics, and education. Evaluation of educational programs about the process of drawing, gathering facts / data and presenting data / information to gather conclusions which will then be used as an consideration of the program, should be fixed, ended or continued. Ralph W Tyler from one of the most popular educational figures. In his view, evaluation is a process to decide whether realisation the goal or not. Determination of whether realization or not a goal, formulate in seven firm / goal-oriented evaluation steps by Tyler. The purpose of reading this article is to explain the concepts, steps and goals of the assessment according to Ralph W Tyler.
\end{abstract}

Keywords: evaluation program, goal-oriented, Tyler approach.

\section{PENDAHULUAN}

Evaluasi sebagai suatu proses untuk memastikan sejauh mana terealisasi atau tidaknya suatu tujuan (Tyler, 1950). Para ahli telah menjelaskan teori dan konsep berkenaan dengan evaluasi dari berbagai perspektif serta cara pandang para ahli itu sendiri. Perbedaan sudut pandang, konsep, kekhasan, dan metodologi yang dimiliki tentunya menjadi latar belakangnya. Sejak awal perkembangan pendidikan evaluasi dari tahun 1960an hingga sekarang, telah banyak model evaluasi yang 
telah dikembangkan dan didasarkan pada bentuk, pendekatan, maupun tujuan evaluasi (Thorndike, et al., 1991). Evaluasi program pendidikan ialah proses penggambaran, menghimpun, dan penyajian fakta/data kepada penarik kesimpulan, selanjutnya akan diaplikasikan sebagai pertimbangan terhadap program tersebut, perlukah dibenahi, disudahi ataupun diteruskan (Muryadi, 2017).

Model evaluasi dapat dikategorikan dalam enam pendekatan yaitu: (1) Objectives/goals-oriented evaluation approach (pendekaatan evaluasi berorientasi pada tujuan). Penilaian pendekatan yang goals oriented telah menstimulasi proses berkembangnya perancangan tujuan secara spesifik serta pengembangan atau penemuan instrumen-instrumen ataupun prosedur pengukuran yang beranekaragam secara teknologis (Tayibnapis, 2008). Berdasarkan kajian dan literature tersebut, Tayibnapis mengemukakan pendekatan penilaian yang goals-oriented telah banyak mengarah pada persoalan bagaimanakah pendekatan tersebut diterapkankan pada penilaian di dalam ruang/kelas, penilaian program sekolah baik pada satu daerah ataupun daerah lainnya; (2) Management-oriented approach (pendekatan berorientasi manajerial/manajemen). Management-oriented approach adalah pendekatan pada penilaian pendidikan yang lebih menekankan pada kebutuhan manajerial. Dengan demikian, pendekatan penilaian yang berorientasi manajemen sangatlah penting dalam membantu para pengambil keputusan; (3) Consumeroriented approaches (pendekatan berorientasi pengguna); (4) Expertise-oriented approach (pendekatan berorentasi kepakaran); (5) The utilization-oriented approach (pendekatan berorientasi utilitas); dan (6) Naturalistic-participantoriented approach (pendekatan berorientasi naturalistik partisipan).

Tujuan penulisan artikel adalah untuk mendeskripsikan pendekatan berorientasi pada tujuan (goals oriented) dan memaparkan konsep, tujuan serta langkah model evaluasi Ralph W Tyler. Satu dari goals evaluasi program yakni diperolehnya informasi/keterangan yang bisa menjadi dasar membuat keputusan, pembentukan kebijakan ataupun pembuatan program selanjutnya. Informasi yang diperoleh haruslah lengkap, valid serta reliabel dan timely (tepat waktu) supaya informasi bisa bermanfaat secara optimal (Munthe, 2015). 
Evaluasi sangat penting bagi berjalannya suatu program, baik program pendidikan, pembelajaran atau pelatihan. Tujuan dari diadakannya evaluasi ialah untuk mengetahui apakah program yang sudah dijalankan seperti program-program tersebut tersampaikan kepada peserta dengan baik atau sesuai dengan target/tujuan dari program tersebut ataukah belum sama sekali. Gall, et al. (2007) mengemukakan bahwa evaluasi pendidikan adalah proses membuat penilaian tentang prestasi, nilai atau nilai program pendidikan.

Sasaran evaluasi bidang pendidikan terdiri dari dua yakni evaluasi makro dan mikro. Evaluasi makro sasarannya ialah program pendidikan kebanyakan/umum, dengan makna lain bahwa program yang dirancang guna perbaikan dalam dunia pendidikan. Sedangkan evaluasi mikro biasanya diterapkan pada tingkat/jenjang kelas artinya sasarannya ialah program kegiatan belajar-mengajar di dalam kelas (Mardapi, 2000). Pendidik memiliki tanggung jawab dalam merancang serta menerapkan program pembelajaran di ruang kelas, sedangkan kepala sekolah bertanggung jawab untuk mengevaluasi program pembelajaran yang dibuat dan dilaksanakan pendidik.

\section{Pengertian Evaluasi Program}

Evaluasi program adalah proses mendeskripsikan, menghimpun informasi/data serta penyajian informasi/keterangan kepada pengambil kesimpulan yang selanjutnya akan digunakan sebagai bahan pertimbangan terhadap program tersebut, perlukah dibenahi, disudahi ataupun diteruskan (Arikunto dan Jabar, 2009). Evaluasi program adalah suatu aktivitas untuk mendapatkan sketsa tentang keadaan suatu objek yang pelaksanannya dengan terstruktur/sistematis, terancang berdasarkan orientasi pada tujuan yang terarah dan jelas (Musa, 2005). Evaluasi merupakan suatu unit kegiatan yang memiliki tujuan menghimpun keterangan/data tentang realisasi dari implementasi kebijakan, yang berkelanjutan pada suatu organisasi yang melibatkan beberapa kelompok individu dalam pembuatan keputusan (Ananda dan Rafida, 2017).

Evaluasi program adalah suatu kegiatan untuk memeriksa sejauh mana kualitas kesuksesan kegiatan yang dirancang (Arikunto, 2005). Evaluasi kerap 
berkaitan dengan pembuatan kesimpulan/keputusan, dikarenakan hasilnya merupakan dasar untuk mengukur suatu program dan bagaimana keputusannya (Ambiyar dan Muharika, 2019). Evaluasi merupakan proses dalam menentukan hasil yang telah dicapai sebagai hasil dari rancangan yang menyokong pencapaian tujuan (Arikunto, 2004).

Evaluation program adalah evaluasi yang mengacu pada sebuah pokok yang menitikberatkan kepada pertanyaan pada fokus perhatian, pengumpulan informasi yang sesuai, selanjutnya dianalisis dan ditafsirkan untuk aplikasi tujuan khusus (Fitzpatrick, et al., 2004). Sedangkan evaluation program sebagai cara melakukan identifikasi pertanyaan yang sesuai, data apa yang hendak dibutuhkan, bagaimana analisis data tersebut serta bagaimana data yang dikumpulkan akan dimanfaatkan (Wholey, 2010).

Berdasarkan teori-teori evaluation program menurut pada ahli tersebut, dapat disimpulkan bahwa evaluation program adalah proses menghimpun informasi secara terstruktur, mendeskripsikan, dan menganalisis data yang kemudian dijadikan dasar dalam pengambilan kesimpulan/keputusan sebagai bahan untuk mempertimbangakan program tersebut, perlukah dibenahi, disudahi ataupun diteruskan (Adjadan, 2015). Model dalam evaluasi program pendidikan yang dipergunakan untuk mengevaluasi keterlaksanaan program yaitu goals-oriented (berorientasi pada tujuan), decision-oriented (berorientasi pada keputusan), transactional-oriented (berorientasi pada kegiatan dan orang-orang yang menanganinya), dan research-oriented (berorientasi pada pengaruh dan dampak program) (Daryanto, 2008). Goals evaluasi menjadi fokus pembahasan dalam kajian yang dilakukan penulis.

Goals evaluasi program dalam dunia kependidikan meliputi delapan aspek, yaitu pengajaran, diagnosis (upaya perbaikan), hasil belajar, fungsi seleksi, penyuluhan (bimbingan), fungsi penempatan, penilaian kelembagaan, dan kurikulum. Evaluasi dari process approach ialah untuk mengetahui ketercapaian tujuan pendidikan dan upaya perbaikan serta pengarahan pelaksanaannya. Selanjutnya, kegiatan pendidikan ditinjau dari pendekatan kelembagaan ialah 
kegiatan yang meliputi perancangan, design, pembuatan program, setting, pelaksanaan pengawasan, dan penilaian.

Eksposisi evaluasi program tersebut diambil kesimpulan evaluasi program ialah suatu upaya menghimpun, merancang, menganalisis, dan mengolah data untuk merumuskan nilai, mutu, kegunaan, prestasi, manfaat dari suatu program, organisasi atau lembaga, kantor, dan sekolah serta lainnya yang selanjutnya akan digunakan sebagai pertimbangan terhadap program tersebut, perlukah dibenahi, disudahi ataupun diteruskan. Implementasi evaluasi program pendidikan untuk memahami tingkat pencapaian program serempak dalam mempertanggung jawabkan program yang telah berproses serta menyampaikan keterangan/informasi kepada pengambil keputusan di fase perancangan/perencanaan (Lazwardi, 2017).

\section{Konsep Pendekatan Evaluasi Berorientasi Tujuan (Goals-Oriented)}

Ralph W Tyler pertama kali memprakarsai pendekatan evaluasi goaloriented pada tahun 1940-1950an sebagai tolok ukur terhadap evaluasi pendidikan. Dahulu untuk melakukan evaluasi di dunia pendidikan dilaksanakan melalui instrumen tes dengan memakai dasar kriteria. Tyler memakai sistematika yang lebih lengkap untuk menautkan hasil yang dicapai siswa dengan yang didambakan. Tyler memformulasikan penilaian hasil belajar dari goal pembelajaran yang didasarkan pada taksonomi yang diuraikan Bloom beserta Krathwohl, yang selajutnya dinamakan orientasi Tyler. Teknik goals-oriented juga dapat dipakai untuk proses evaluasi program lain, misalnya bidang kesehatan. Dalam perkembangan selanjutnya, orientasi Tyler juga dikembangkan oleh beberapa ahli, seperti Metfessel dan Michael (1967), Hammond (1973), dan Provus (1973). Beberapa pendekatan tersebut memiliki ciri yang sama, yaitu inti evaluasi program tersebut sejauh mana tujuan telah dicapai setelah program dilaksanakan.

Evaluasi pendidikan sebagai satu proses bagaimana mendefenisikan pencapaian tujuan/target pendidikan dari kurikulum atau program sekolah (Oriondo dan Eleanor, 1998). Evaluasi program goals-oriented Tyler dirancang untuk mendeskripsikan pencapaian tujuan suatu program. Tyler menerapkan kesenjangan antara harapan dan yang teramati sebagai masukan atau pertimbangan 
pada kekurangan dari kegiatan program orientasi tersebut yang menitikberatkan pada goal khusus suatu kegiatan serta bagimana hasil pencapaian program tersebut.

Menentukan pencapaian tujuan kegiatan/program pendidikan, Tyler menguraikan beberapa tahap penilaian pendidikan, yakni penetapan tujuan global atau umum, mengelompokkan/mendeskripsikan sasaran/target, menentukan situasi pencapaian tujuan yang ditetapkan, mengembangkan teknik penilaian, menghimpun serta membandingkan data unjuk kerja dengan sikap/karakter yang mendeskripsikan tujuan. Setelah setiap tahap berakhir, dapat diketahui ketimpangan antara tujuan dan hasil yang diharapkan. Selanjutnya hasil tersebut dipakai sebagai pengoreksi kelemahan program, kemudian pengulangan dapat dilakukan kembali pada tahap tersebut. Pandangan Tyler secara rasional dapat disambut baik dan digunakan oleh para praktisi pendidikan dalam kegiatan evaluasi. Tyler juga menerapkan posttest dan pretest untuk dipakai sebagai instrument dalam penilaian. Teknik pretest-posttest bertujuan untuk menetapkan perubahan yang berlaku bagi perseorangan, program/kegiatan serta banyaknya perubahan.

Tyler menguraikan 6 (enam) goals-oriented dari sekolah, yaitu: memperoleh informasi; mengembangkan keterampilan atau kompetensi belajar; membangun berpikir yang inovatif dan efektif; penanaman perilaku, minat, kepekaan sosial, dan apresiasi; serta menumbuhkan falsafah hidup (makin lama seseorang belajar, maka filosofis hidupnya akan meningkatkan, dari tidak mengerti menjadi mengerti). Tyler menerangkan pentingnya mencermati aspek sikap dalam mengembangkan tujuan pembelajaran di sekolah. Tyler menegaskan pentingnya filtrasi tujuan umum sebagai dasar untuk melakukan evaluation program. Di bidang pendidikan, cara mengfiltrasinya untuk menyusun pertanyaan-pertanyaan yang berfaedah tentang pedagogis, filsafat maupun sosial.

Metode realitas untuk mengevaluasi tujuan yakni: (1) Menghimpun data dalam menggambarkan nilai/tujuan; (2) Mempertimbangkan pendapat forum untuk meninjau kembali, serta melakukan evaluasi tujuan; (3) Mengumpulkan data dokumen dari berbagai sumber, seperti catatan atau arsip editorial; dan (4) Menganalisis apakah tujuan yang diharapkan tercapai. Beberapa strategi 
menghimpun data pada evaluasi, bergantung dari tanggapan atau jawaban atas beberapa poin pertanyaan dasar untuk melaksanakan evaluasi terhadap program atau kegiatan, yaitu: (1) Siapa yang memerlukankan evaluasi dan kepada siapa informasi itu?; (2) Seperti apa informasi yang diperlukan?; (3) Bagaimana data atau informasi itu akan digunakan; (4) Kapan data atau informasi dibutuhkan; dan (5) Apa referensi yang mungkin bisa digunakan saat melaksanakan evaluasi.

Tyler mendefinisikan evaluasi pendidikan adalah satu proses untuk menentukan sejauh mana ketercapaian program atau kurikulum sekolah ditinjau tujuan-tujuan pendidikan. Langkah-langkah evaluasi Tyler terdiri dari: (1) Merumuskan tujuan secara jelas; (2) Melakukan klasifikasi tujuan; (3) Merumuskan tujuan pada istilah perilaku secara terukur; (4) Menentukan kapan pencapaian tujuan dapat ditunjukkan; (5) Memilih dan mengembangkan metode pengukuran yang tepat; (6) Menghimpun informasi atau data; dan (7) Menganalogikan data atau infomasi prestasi pada tujuan yang dituangkan pada karakter yang ternilai. Untuk lebih jelasnya dapat dilihat pada Gambar 1.

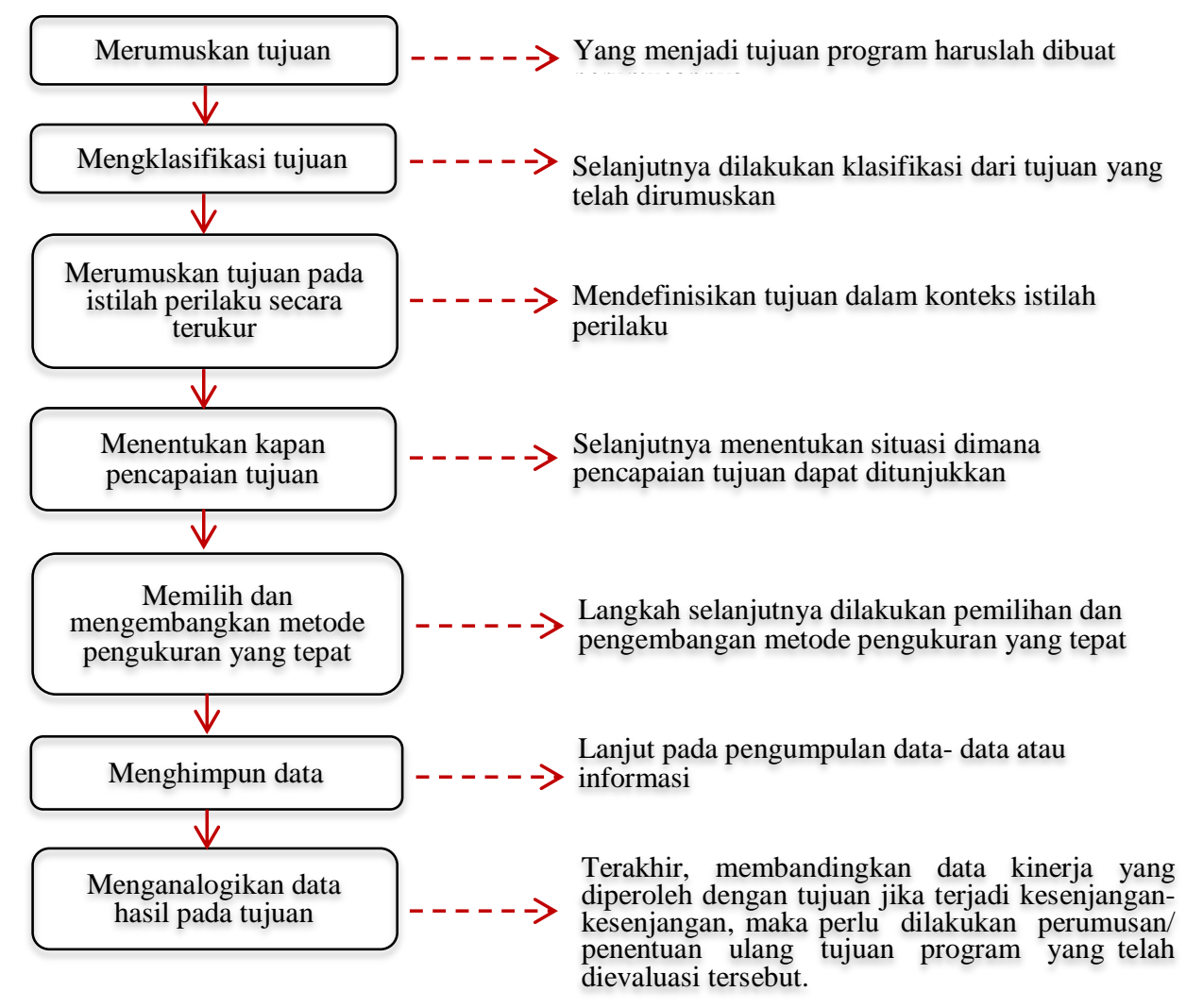

Gambar 1 Langkah-Langkah Model Evaluasi Tyler 
Berakhirnya langkah tersebut, selanjutnya dilakukan rangkaian yang berarti data atau informasi kinerja dibandingkan pada tujuan dan diperoleh berupa ketimpangan, kemudian dilakukan perumusan ulang terhadap tujuan program dari evaluasi tersebut. Jika diperhatikan dengan saksama, langkah atau tahapan tersebut terdapat dua komponen penting, yakni komponen yang berkaitan dengan kegiatan program perancangan (tahap pertama sampai ketiga) dan komponen yang secara langsung berkaitan dengan kegiatan program dalam tahap evaluasi program (tahap keempat dan seterusnya).

Rangkaian kegiatan yang dimaksud ialah rangkaian kegiatan pengelolaan serta pengembangan program sebab ide atau gagasan ini dirancang dalam rencana pengembangan kurikulum. Mindset yang Tyler promosikan dapat diterima secara logis dan ilmiah, sangatlah masuk akal, serta mudah ditiru dan dilakukan oleh para evaluator pelaksana. Contoh penerapan model tersebut adalah dengan membandingkan pretest dengan posttest.

Berdasarkan pemaparan terebut, penulis merangkum hasil analisis dari model Tyler tersebut sebagai berikut: (1) Model Tyler fokus pada pengukuran perspektif tujuan yang telah ditetapkan dalam kerangka kerja tercapai ataupun sebaliknya; (2) Model Tyler tentu tidak mengevaluasi yang diluar dari tujuan rancangan program atau kegiatan tersebut; (3) Evaluasi fokus pada akhir program untuk mengukur apakah tujuan tersebut tercapai; (4) Evaluasi tidak mengukur dampak positif atau negatif dari program tersebut; dan (5) Evaluasi tidak akan mengukur apa yang dialami siswa yang tidak lulus, apa yang siswa rasakan dan sebagainya.

Menurut beberapa poin definisi para ahli, bisa pahami evaluation program menganalogikan yang sudah dicapai pada kegiatan/program berlandaskan pada kriteria yang sudah ditetapkan untuk tercapainya pelaksanaan kegiatan program, sebaliknya yang perlu dinilai yaitu proses serta hasil untuk mengambil suatu kesimpulan atau keputusan. Evalution bisa digunakan untuk mengetahui sejauh mana keberhasilan kegiatan atau program, kemudian diambil suatu keputusan apakah program diteruskan, ditunda, dikembangkan, ditingkatkan, diterima atau ditolak. 
Salah satu penerapan model evaluasi oleh Tyler adalah bagaimana melakukan pengukuran tes kemampuan awal siswa (pretest) dibandingkan dengan hasil pengukuran paska kegiatan pembelajaran (posttest). Kegiatan tersebut menjadi salah satu teknik yang banyak berpengaruh terhadap cara-cara penilaian program pembelajaran di dunia pendidikan. Contoh yang dilakukan Tyler banyak dilakukan oleh guru-guru dalam melakukan penilaian keberhasilan program pembelajaan di kelas. Secara praktis, pendekatan Tyler memang tidak terlalu menyita waktu karena hanya dilakukan pada akhir kegiatan pembelajaran. Pendekatan Tyler sangat sejalan dengan tradisi pemikiran manajemen/pengelolaan yang menempatkan kegiatan evaluasi sebagai kegiatan terakhir.

Kajian yang penulis laksanakan dengan pengumpulan informasi dari jurnal, buku-buku, dan rujukan lainnya yang terkait dengan masalah serta tujuan riset. Jurnal dan buku-buku/literatur lain adalah sebagai resources data/informasi yang selanjutnya diolah serta ditelaah. Penulisan kajian dilakukan dengan menghimpun beberapa sumber kepustakaan untuk mendapatkan keterangan /informasi yang bersifat teoretis.

\section{SIMPULAN}

Evaluasi program goals-oriented dari Tyler dirancang untuk mendeskripsikan tujuan program yang telah berhasil. Evaluasi bermakna juga bagi pengambilan kesimpulan yang mencakup tiga hal utama dalam proses tersebut, yaitu merumuskan pertanyaan, menghimpun data, dan menyajikan atau menampilkan informasi. Evaluasi kontributif memiliki keunggulan dalam proses pengambilan keputusan dalam pendekatan evaluasi goals-oriented yaitu kelugasannya. Pendekatan evaluasi goals-oriented cepat diikuti, dipahami, diaplikasikan serta mudah disetujui serta dikuasai saat diteliti. Tyler menguraikan 5 (lima) goals-oriented dari sekolah, yaitu: memperoleh informasi; mengembangkan keterampilan atau kompetensi belajar; membangun pola pikir yang inovatif dan efektif; penanaman prilaku, minat, kepekaan sosial, dan apresiasi; serta menumbuhkan falsafah hidup (makin lama seseorang belajar, maka filosofis hidupnya akan meningkatkan, dari tidak mengerti menjadi mengerti). 


\section{DAFTAR PUSTAKA}

Adjadan, S. 2015. Evaluasi Program Pendidikan dan Pelatihan Calon Kepala Sekolah (Studi Evaluatif Pascadiklat di LPMP Provinsi Maluku Utara). Jurnal Evaluasi Pendidikan, 17(3): 164-175.

Ambiyar \& Muharika. D. 2019. Metodologi Penelitian Evaluasi Program. Bandung: Alfabeta.

Ananda, R. \& Rafida, T. 2017. Pengantar Evaluasi Program Pendidikan. Medan: Perdana Publishing.

Arikunto, S. 2005. Evaluasi Program Pendidikan. Jakarta: Bumi Aksara.

Arikunto, S. 2004. Dasar-Dasar Evaluasi Pendidikan. Jakarta: Bumi Aksara.

Arikunto, S. \& Jabar, C. S. A. 2009. Evaluasi Program Pendidikan: Pedoman Teoretis Praktis bagi Mahasiswa dan Praktisi Pendidikan. Jakarta: Bumi Aksara.

Daryanto, 2008. Evaluasi Pendidikan. Jakarta: Rineka Cipta.

Fitzpatrick, J. L., James, R. S. \& Blaine, R. W. 2004. Program Evaluation Alternative Approaches and Practical Guidelines. Pearson Education Inc: Boston.

Gall, M. D., Gall, J., \& Borg, W. R. 2007. Educational Research: An Introduction. New York: Pearson Education.

Lazwardi, D. 2017. Implementasi Evaluasi Program Pendidikan di Tingkat Sekolah Dasar dan Menengah. Al-Idarah: Jurnal Kependidikan Islam, 7(2): 142-156.

Mardapi, D. 2000. Evaluasi Pendidikan. Makalah disampaikan pada Konvensi Pendidikan Nasional tanggal 19-23 September 2000 di Universitas Negeri Jakarta.

Musa, S. 2005. Evaluasi Program Pembelajaran dan Pemberdayaan Masyarakat. Bandung: Y-Pin Indonesia.

Munthe, A. P. 2015. Pentingya Evaluasi Program di Institusi Pendidikan: Sebuah Pengantar, Pengertian, Tujuan, dan Manfaat. Jurnal Scholaria, 5(2):1-14.

Muryadi, A. D. 2017. Model Evaluasi Program dalam Penelitian Evaluasi. Jurnal Ilmiah PENJAS, 3(1): 1-16.

Oriondo, L. L. \& Eleanor, M. D. A. 1998. Evaluating Educational, Outcomes. Manila: Rex Book Store.

Tayibnapis, F. Y. 2008. Inovasi Program dan Instrumen Evaluasi untuk Program Pendidikan dan Penelitian. Jakarta: PT Rineka Cipta.

Tyler, R. 1950. Models of Teaching. New Yersey: Prentice-Hall, Inc. Englewood Cliffs.

Thorndike, R. M., Cunningham, G. K., Thorndike, R. L., \& Hagen, E. P. 1991. Measurement and Evaluation in Psychology and Education (5th ed.). New York: Macmillan Publishing Co, Inc.

Wholey, S. J. 2010. Handbook Of Practical Program Evaluation. San Fransisco: Jossey-Bass. 